\title{
Peer support and access to information as predictors of HIV testing among indirect female sex workers in Bali, Indonesia
}

\author{
Putu Erma Pradnyani ${ }^{1}$, Pande Putu Januraga ${ }^{2}$, Mahmudah $^{1}$, Arief Wibowo ${ }^{1}$ \\ ${ }^{1}$ Faculty of Public Health, Airlangga University, Jawa Timur 60115, Indonesia \\ ${ }^{2}$ Department of Public Health and Preventive Medicine, Faculty of Medicine, Udayana University, Bali, Indonesia
}

\begin{abstract}
Introduction: Human immunodeficiency virus (HIV)/acquired immune deficiency syndrome (AIDS) epidemic in most Asian countries is concentrated among at-risk populations, such as female sex workers (FSWs). In Indonesia, Bali's FSWs have a high-rate of HIV infection. This study investigates the predictors of HIV testing among indirect female sex workers (IFSWs) in Denpasar, Bali.

Material and methods: The researchers conducted an analysis of secondary data from a survey performed among IFSWs in Denpasar Bali in 2017. There were 200 IFSWs participating in the survey using random cluster sampling. The dependent variables examined in this study was HIV testing, while the independent variables included: 1) respondent's demographics (age, education level, marital status, work location, and length of work), 2) peer support, and 3) access to information about HIV prevention. The association between independent and dependent variables were analyzed using multiple logistic regression models.

Results: The results showed that $70.0 \%$ of IFSWs in Denpasar have accessed HIV testing in the last 6 months and received their test results. Also, 56.5\% of the study's respondents reported a lack of peer support in relation to HIV/AIDS, and 63.5\% reported having adequate access to information about HIV testing. The logistic multiple regression results revealed that two factors were significant predictors of HIV testing among IFSWs, such as adequate access to information about HIV testing and prevention ( $\mathrm{OR}=2.21$; 95\% CI: $1.15-4.30)$, and peer support ( $\mathrm{OR}=2.29$; 95\% CI: $1.21-4.34$ ).

Conclusions: Efforts to improve the provision of information about HIV testing and prevention as well as peer support related to HIV/AIDS are required to increase the numbers of IFSWs accessing HIV testing.
\end{abstract}

HIV AIDS Rev 2020; 19, 3: 206-211

DOI: https://doi.org/10.5114/hivar.2020.97952

Key words: female sex workers, HIV, information, support.

\section{Introduction}

Human immunodeficiency virus (HIV) and acquired immune deficiency syndrome (AIDS) remain serious global public health issues. In 2016, 1.8 million new cases of HIV were diagnosed globally, resulting in 36.7 million people living with HIV/AIDS in the same year [1]. In most Asian countries, HIV/AIDS is concentrated among populations including female sex workers (FSWs), homosexual men, people who inject drugs (PWIDs), and transgender males
Address for correspondence: Pande Putu Januraga, Department of Public Health and Preventive Medicine, Faculty of Medicine, Udayana University, Jalan PB Sudirman, Denpasar-Bali, Indonesia, 80232,e-mail: januraga@unud.ac.id
Article history:

Received: 15.01 .2020

Received in revised form: 25.02.2020

Accepted: 03.03.2020

Available online: 30.07 .2020
International Journal of HIV-Related Problems

HIV \& AIDS

$R$ e $v$ i e w 
(or 'waria'). In the Asia Pacific region, at-risk populations and their sexual partners accounted for $35 \%$ of new HIV infections in 2017 [2].

Further, a meta-analysis of data from 77 countries showed that the proportion of FSWs as compared to the total number of adult females is strongly associated with the prevalence of HIV in the general population of these countries [3]. In Indonesia, a total number of 226,791 FSWs was estimated, which comprised of both direct female sex worker (DFSWs) and IFSWs [4]. DFSWs are defined as brothel-based female sex workers, where women sell sex directly at their working place, while IFSWs are defined as women that sell sex covertly in bars, massage parlors, etc. [5].

In line with economic development and government policy related to reducing prostitution, the number of DFSWs tended to decrease, while the number of IFSWs was increasing [6]. For example, in 2015, there were an estimated 73,900 DFSWs and 150,800 IFSWs [4]. IFSWs has different working environment from DFSWs, with higher alcohol and drugs consumption, which may increase the risk of unprotected sex. Furthermore, with covert working environment, IFSWs are less likely to benefit from health promotion program [7]. Thus, with the increasing number of IFSWs, more attention to this group of sex workers is needed.

Although the number of sex workers is smaller than other at-risk populations affected by HIV and AIDS, sex workers are thought to be an important route of HIV infection to the general population in Indonesia through infecting their customers [8]. In Indonesia, an estimated 5,254,663 men use FSWs' services, and heterosexual intercourse represents the dominant route of HIV transmission [4]. The 2015 integrated biological and behavioral survey (IBBS) reported that $7.7 \%$ of DFSWs and $2.20 \%$ of IFSWs in Indonesia were HIV-positive [5]. Sex workers in Bali have a relatively high-rate of HIV infection, while the 2018 IBBS did not differentiate FSWs into DFSWs and IFSWs, and using the definition above and applying at the sampling frame, the HIV rate among IFSWs was 5\% in 2018 [9].

In line with global anti-HIV campaigns, such as the UNAIDS' 90-90-90 initiative to prevent the transmission of HIV/AIDS [10], since 2015, the Indonesian government has supported various efforts to increase HIV testing coverage and treatment among all sex workers in Indonesia, including those in Bali. With funding support from the Global Funds (GF), HIV control programs consider the number of HIV tests performed, new cases of HIV detected, and HIV treatment coverage as indicators of success [11]. Nevertheless, a model estimated that only just over half (51\%) of those living with HIV in Indonesia are aware of their HIV-positive status [12]. Efforts to improve HIV testing coverage and discover new cases of infection are ongoing. Strategies to improve HIV testing coverage have involved enabling community health centers (puskesmas) to provide HIV testing services and counselling as well as offering mobile HIV testing. Furthermore, a peer educator (PE) model to allow women to access health promotion modalities, HIV testing, and treatment facilities has also been campaigned [13].
Several studies have highlighted that sex workers' willingness to access HIV testing is influenced by various factors, such as demographics, media information, and peer support [14-16]. Other factors that influence the uptake of HIV testing are knowledge, length of time working in the sex trade, and level of support available in the vicinity $[17,18]$. Although a significant number of studies have investigated the determinants of HIV testing among FSWs, there is a lack of research that specifically explores the determinants of HIV testing of IFSWs. It is hoped that the present study will fill this gap.

\section{Material and methods}

\section{Study design}

This research project adopted a quantitative cross-sectional approach using data from a research project conducted by the Center for Public Health Innovation (CPHI) at the Faculty of Medicine, Udayana University, Bali, Indonesia. The research project is entitled "The Social Capital Survey and Internet Utilization among Indirect Female Sex Workers in Denpasar, Bali, in 2017", and data collection was conducted from August to October 2017. This study used random cluster sampling to collect data from 200 indirect sex workers in Denpasar, Bali. Details of the method used to recruit study respondents is described elsewhere [19].

\section{Variables}

Because the original study used exploratory sequential order research, specific themes and statements related to the access to information and peer support obtained from the qualitative data were used to develop a survey instrument, which was adjusted to the views and language of the participants. The survey questions were also developed from the results of a previous qualitative study conducted in Bali [20]. The instruments were field-tested to check its applicability and ease of flows.

In the current study, the dependent variable was the successful completion of a HIV test within the past 6 months, where the results have been accepted by the tested person. The independent variable consisted of three main factors:

1. The first dependent variable was the respondent's demographic characteristics. The respondents were divided into three age groups categories: $<20$ years, 20-35 years, and $>35$ years. Education level was grouped into two categories, namely low and high. Respondents were assigned to the low education group if they had only been educated up to junior high school level, while those who had completed high school or above were assigned to the high group. Marital status was divided into three categories, i.e. unmarried, married, and divorced. The length of work in the sex trade was grouped into two periods, such as $<1$ year and $\geq 1$ year. Workplace types were grouped into three categories: A - Spas, B - karaoke establishments, and $\mathrm{C}$ - cafes and bars. 
2. The second dependent variable was peer support, which was measured by the respondent's answers to six statements assessing the level of peer support they felt they received related to HIV prevention, namely the use of condoms and the support sex workers received at their workplace. This survey uses a 1-5 Likert scale that is grouped based on a median value: those who reported receiving peer support (high) were assigned $\mathrm{a} \geq$ median score, while those who reported receiving no peer support (low) were assigned $\mathrm{a}<$ median score.

3. The third variable was IFSW' access to information about HIV/AIDS through the media and the Internet. This was measured via the four-information disclosure statement (yes and no). This variable was grouped according to the median value (e.g., 'good access' $\geq$ median; 'poor access' $<$ median).

\section{Statistical analysis}

SPSS version 21.0 was used to perform the univariate and multivariate logistic regression analysis. This multivariate analysis was used to identify factors that could potentially influence HIV testing uptake among this population. Multiple logistic regression model was performed with a bivariate analysis with $p$-value $=0.25$. The level of significance for the logistic regression test was set at $p<0.05$.

\section{Research ethics}

Ethical approval was received from the Health Research Ethics Committee, Faculty of Public Health, Airlangga University, code number 102/EA/KEKP/2019. Each participant received oral and written information about the study from the researchers. The participants were considered to have agreed to take part in the study if they gave their consent to answer the survey questions. This type of consent is considered best practice in research with marginalized and highrisk populations [21].

\section{Results}

Demographic analysis of the 200 indirect sex workers in Denpasar was based on age, education, marital status, length of work in the sex trade, and workplace type. Participants' mean and median age was $29(\mathrm{SD}=7.11 ; \mathrm{IQR}=10)$. Just over three-quarters of the participants (76.0\%) were of childbearing age for women (between $20-35$ ). $54 \%$ of participants were relatively well educated, i.e. being educated to high-school level or above. While most participants have been married, widows/ divorcees accounted for the largest proportion (59.5\%), while the rest were unmarried or married. In terms of workplace type, most participants generally worked in cafes and bars (36.5\%), with the majority reporting having worked as indirect sex workers for over one year (87\%).
In terms of the results for variables, peer support, and access to information about HIV/AIDS, the participants' overall median peer support score was 20 , while the median score for access to information was 2 . Based on these median scores, the study showed that $56.5 \%$ of participants reported not receiving adequate peer support in relation to HIV/AIDS, while $63.5 \%$ stated having 'good access' to information about HIV/AIDS. Also, analysis of the results showed that $70 \%$ of the respondents reported already using HIV testing services and having received their results within the last six months (Table 1).

Table 2 provides a crude logistical regression analysis to illustrate the relationship between each independent variable and the uptake of HIV testing. Of those IFSWs sampled who reported having a 'good' level of access to information about HIV/AIDS, 76.4\% have undergone HIV testing and received their results within the last six months. However, of those who reported having poor access to information about HIV/AIDS, only $58.9 \%$ had undergone HIV testing

Table 1. Demographic profile of the indirect female sex workers investigated $(n=200)$

\begin{tabular}{|c|c|}
\hline Characteristics & $n(\%)$ \\
\hline \multicolumn{2}{|l|}{ HIV test } \\
\hline Yes & $140(70.0)$ \\
\hline No & $60(30.0)$ \\
\hline \multicolumn{2}{|l|}{ Age } \\
\hline$<20$ years & $16(8.0)$ \\
\hline 20-35-year-old & $152(76.0)$ \\
\hline$>35$ years & $32(16.0)$ \\
\hline \multicolumn{2}{|l|}{ Education } \\
\hline Low & $92(46.0)$ \\
\hline High & $108(54.0)$ \\
\hline \multicolumn{2}{|l|}{ Marital status } \\
\hline Unmarried & $51(25.5)$ \\
\hline Married & $30(15.0)$ \\
\hline Widowed/divorced & $119(59.5)$ \\
\hline \multicolumn{2}{|l|}{ Workplace } \\
\hline Spa & $62(31.0)$ \\
\hline Karaoke & $65(32.5)$ \\
\hline Cafe and bar & $73(36.5)$ \\
\hline \multicolumn{2}{|c|}{ Length of time in the sex trade } \\
\hline$<1$ year & $26(13.0)$ \\
\hline$\geq 1$ year & $174(87.0)$ \\
\hline \multicolumn{2}{|l|}{ Peer support } \\
\hline Yes & $113(56.5)$ \\
\hline No & $87(43.5)$ \\
\hline \multicolumn{2}{|l|}{ Access to information } \\
\hline Good access & $127(63.5)$ \\
\hline Poor access & $73(36.5)$ \\
\hline
\end{tabular}


Table 2. Bivariate analysis of factors associated with HIV testing uptake of indirect female sex workers

\begin{tabular}{|c|c|c|c|c|c|}
\hline Factor & $\begin{array}{c}\text { Using VCT } \\
n(\%)\end{array}$ & $\begin{array}{c}\text { No using VCT } \\
n(\%)\end{array}$ & $p$-value & OR & $95 \% \mathrm{Cl}$ \\
\hline \multicolumn{6}{|l|}{ Age } \\
\hline$<20$ & $11(68.8)$ & $5(31.3)$ & Ref & Ref & \\
\hline $20-35$ & $106(69.7)$ & $46(30.3)$ & 0.935 & 1.047 & $0.35-3.19$ \\
\hline$>35$ & $23(71.9)$ & $9(28.1)$ & 0.822 & 1.162 & $0.31-4.30$ \\
\hline \multicolumn{6}{|l|}{ Education level } \\
\hline Low & $11(68.8)$ & $5(31.3)$ & Ref & Ref & \multirow[t]{2}{*}{$0.57-1.91$} \\
\hline High & $106(69.7)$ & $46(30.3)$ & 0.901 & 1.039 & \\
\hline \multicolumn{6}{|l|}{ Marital status } \\
\hline Unmarried & $33(64.7)$ & $18(35.3)$ & Ref & Ref & \\
\hline Married & $19(63.3)$ & $11(36.7)$ & 0.901 & 0.942 & $0.37-2.41$ \\
\hline Widow & $88(73.9)$ & $31(26.1)$ & $0.224^{\star}$ & 1.548 & $0.77-3.14$ \\
\hline \multicolumn{6}{|l|}{ Workplace } \\
\hline Spa & $44(71.0)$ & $18(29.0)$ & Ref & Ref & \\
\hline Karaoke & $43(66.2)$ & $22(33.8)$ & 0.560 & 0.800 & $0.38-170$ \\
\hline Cafe and bar & $53(72.6)$ & $20(27.4)$ & 0.833 & 1.084 & $0.51-2.30$ \\
\hline \multicolumn{6}{|c|}{ Length of time in the sex trade } \\
\hline$<1$ year & $14(53.8)$ & $12(46.2)$ & Ref & Ref & \multirow[t]{2}{*}{$0.19-1.03$} \\
\hline$\geq 1$ year & $126(72.4)$ & $48(27.6)$ & $0.058^{*}$ & 2.250 & \\
\hline \multicolumn{6}{|l|}{ Peer support } \\
\hline Yes & $89(78.8)$ & $24(21.2)$ & $0.002^{*}$ & 2.618 & \multirow[t]{2}{*}{$0.21-0.71$} \\
\hline No & $51(58.6)$ & $36(41.4)$ & Ref & Ref & \\
\hline \multicolumn{6}{|c|}{ Access to information } \\
\hline Good access & $97(76.4)$ & $30(23.6)$ & $0.010^{\star}$ & 2.256 & \multirow[t]{2}{*}{$1.21-420$} \\
\hline Poor access & $43(58.9)$ & $30(41.1)$ & Ref & Ref & \\
\hline
\end{tabular}

Table 3. Multivariate logistic regression model of the predictor of HIV testing uptake of indirect female sex workers

\begin{tabular}{|c|c|c|c|}
\hline \multirow[t]{2}{*}{ Variable } & \multicolumn{3}{|c|}{ Multivariate model } \\
\hline & $p$-value & $\mathrm{aOR}$ & $95 \% \mathrm{Cl}$ \\
\hline \multicolumn{4}{|l|}{ Marital status } \\
\hline Unmarried & - & Ref & - \\
\hline Married & 0.957 & 1.03 & $0.38-2.81$ \\
\hline Divorced & 0.134 & 1.77 & $0.84-3.75$ \\
\hline \multicolumn{4}{|c|}{ Length of time in the sex trade } \\
\hline$<1$ year & \multirow[t]{2}{*}{0.121} & Ref & \multirow[t]{2}{*}{$0.83-4.97$} \\
\hline$\geq 1$ year & & 2.03 & \\
\hline \multicolumn{4}{|l|}{ Peer support } \\
\hline No & \multirow[t]{2}{*}{$0.011^{\star * *}$} & Ref & \multirow[t]{2}{*}{$1.21-4.34$} \\
\hline Yes & & 2.29 & \\
\hline \multicolumn{4}{|l|}{ Information access } \\
\hline Poor access & \multirow[t]{2}{*}{$0.018^{\star \star \star}$} & Ref & \multirow[t]{2}{*}{$1.15-4.30$} \\
\hline Good access & & 2.21 & \\
\hline
\end{tabular}

$(p=0.010)$. Meanwhile, peer support has a significant relationship with the uptake of HIV testing $(p=0.002)$. Over three-quarters $(78.8 \%)$ of the indirect sex workers sampled, who reported receiving peer support reported having undergone HIV testing, while $58.6 \%$ of those who reported getting no support admitted getting tested for HIV. Participants' demographic characteristics (education level, age group, marital status, work location, and period of work as indirect sex workers) did not influence their willingness to undergo HIV testing $(p>0.05)$.

The multivariate logistic regression model included four variables, with a $p$-value of $<0.25$ (Table 2). The analysis found only two variables related to HIV testing within the last 6 months (Table 3) and included access to information about HIV/AIDS $(\mathrm{aOR}=2.21 ; 95 \% \mathrm{CI}=1.15-4.30)$ and peer support $(\mathrm{aOR}=2.29 ; 95 \% \mathrm{CI}=1.21-4.34)$. The adjusted OR values show that indirect sex workers that report having better peer support for HIV/AIDS-related issues were 2.3 times more likely to engage in HIV testing. Indirect sex workers who reported 'good' access to information about HIV/AIDS were 2.2 times more likely to seek 
HIV testing compared to those who reported having a lack of information about HIV/AIDS. The analysis resulted in $80 \%$ of model accuracy meaning that the ability of access to information and peer support to predict HIV testing was relatively good.

\section{Discussion}

Female sex workers, including IFSWs, represent one of the key populations vulnerable to HIV infection via sexual intercourse $[5,19]$. In general, sex workers are poorly informed about health issues, and/ or have inaccurate perceptions about the risks of HIV infection and other STI-related issues [17]. Female sex workers are also the subject of fear of stigma among the local community if their HIV status becomes known, which can lead to being reluctant to be open about HIV testing and their HIV status [22, 23].

The present study shows that $70 \%$ of IFSWs have accessed HIV testing within the past 6 months and have received their test results. However, this figure is lower than that observed by the 2015 IBBS study, where $81 \%$ of IFSWs reported of having undergone HIV testing [5]. Thus, when compared to the HIV care continuum's first target (i.e., by 2020, 90\% of all people living with HIV will know their HIV status), additional efforts are still necessary for Bali to achieve the target of $90 \%$ of HIV testing among this population. Furthermore, increasing this first step of the cascade is important, since the recent report related to the HIV care flow in Indonesia including Bali, reported poor treatment uptake and retention in treatment [24].

The multiple logistic regression showed that access to information and peer support plays a significant role as a predictor of HIV testing among the participants. This finding is in line with other related studies that showed the access to high-quality information about HIV testing services resulting in an increase of the proportion of sex workers seeking HIV testing. Offering sex workers accurate high-quality information about HIV tends to create a positive perception of HIV testing [25]. Other studies carried out in Sub-Saharan Africa and Thailand suggested that the provision of mobile services to the community and the provision of information about HIV (by mobile VCT teams) increased HIV testing coverage [26].

Furthermore, the results of the logistic regression model highlighted that peer support has the most significant influence on the uptake of HIV testing. A study in Bali on direct sex workers showed that improving peer support and social capital among sex workers could improve the exchange of information about HIV and strengthen their motivation to participate in HIV/AIDS prevention initiatives, such as HIV testing [20]. Peer support from individuals that share the same living/ working environment or life situation, such as in the case of sex workers, has a greater influence on their willingness to take up HIV testing opportunities compared to encouragement from external agents (i.e., health workers) [27, 28].

These findings are also in line with previous research that identified a relationship between the quality of me- dia information about HIV and the level of peer support among women sex workers concerning their willingness to undergo HIV testing in organized brothels/ red-light areas [18]. Improving awareness about the importance of HIV testing represents the first step to prevent negative health outcomes for HIV-positive sex workers as well as ensuring that those who are HIV-negative (non-reactive) remain uninfected, and these efforts must be both continuous and constant [29]. In the era of 'test-and-treat' policy, early treatment interventions for those who are HIV-positive will reduce the risk of HIV transmission to their sexual partners.

Looking at the national strategy to control HIV epidemic among sex workers, the government of Indonesia has implemented an initiative to provide a standard HIV-prevention outreach package, combined with the development of a peer-support model [13]. However, considering that still, a relatively significant proportion of IFSWs in this study have not undergone regular HIV testing, there is a need to develop further innovations related to providing information about HIV and creating effective social/ peer support models. For example, these could include social media campaigns, smartphone applications, and other Internet-related initiatives. Moreover, other innovative approach, e.g., using self-testing method, could also be considered in the future. A study in Zambia among FSWs revealed that self-testing provides entry point for HIV prevention services [30].

\section{Conclusions}

Only $70 \%$ of indirect sex workers in Denpasar undergo HIV testing. The results of the multiple logistic regression analysis revealed that two variables are significant predictors of indirect sex workers' willingness to undergo HIV testing, namely access to information about HIV and peer support. These results emphasize the urgent need to improve the propagation of information about HIV and to strengthen indirect sex workers' peer support networks. This could be achieved through developing innovative social media campaigns, smartphone applications, and Internet-related initiatives, targeted at the prevention of the spread of HIV among indirect sex workers. Considering the above-mentioned, further innovative approach, such as self-testing as well as more researches are required to develop effective initiatives that achieve these aims.

\section{Acknowledgments}

The researchers would like to thank the CPHI for giving their permission to use the research data as well as the respondents who participated in this study.

\section{Conflict of interest}

The authors declare no conflict of interest with respect to the research, authorship, and/or publication of this article. 


\section{References}

1. United Nations Programme on HIV/AIDS (UNAIDS). UNAIDS data 2017. Geneva; 2017.

2. United Nations Programme on HIV/AIDS (UNAIDS). UNAIDS data 2018. Geneva; 2018.

3. Talbott JR. Size matters: The Number of Prostitutes and The Global HIV/AIDS Pandemic. PLoS One 2007; 2: e543. DOi: https://doi. org/10.1371/journal.pone.0000543.

4. Ministry of Health. Estimate and Projection of HIV/AIDS in Indonesia 2015-2020. Jakarta; 2017.

5. Ministry of Health. Survei Terpadu Biologis dan Perilaku [Integrated Biological and Behaviour Survey]. Jakarta; 2015.

6. Januraga PP, Wulandari LPL, Muliawan P, et al. Sharply rising prevalence of HIV infection in Bali: a critical assessment of the surveillance data. Int J STD AIDS 2013; 24: 633-637.

7. Harcourt C, Donovan B. The many faces of sex work. Sex Transm Infect 2005; 81: 201-206.

8. Rahmalia A, Wisaksana R, Meijerink H, et al. Women with HIV in Indonesia: are they bridging a concentrated epidemic to the wider community? BMC Res Notes 2015; 8: 757.

9. Ministry of Health. Survei Terpadu Biologis dan Perilaku 20182019 [Integrated Biological and Behaviour Survey]. Jakarta; 2018.

10. United Nations Programme on HIV/AIDS (UNAIDS). Ending AIDS: Progress Toward The 90-90-90 Targets. Geneva; 2017.

11. The Global Fund. Audit Report: Global Fund Granst to the Republic of Indonesia. Geneva; 2015.

12. United Nations Programme on HIV/AIDS (UNAIDS). Indonesia 2019 UNAIDS data; 2019.

13. Ministry of Health of Indonesia. National Action Plan on HIV-AIDS. Jakarta; 2015.

14. Nnko S, Kuringe E, Nyato D, et al. Determinants of access to HIV testing and counselling services among female sex workers in sub-Saharan Africa: A systematic review. BMC Public Health 2019; 19: 15 .

15. Mohammed MF. Access to voluntary counseling and testing services for female sex workers and men who have sex with men in Yemen. J Infect Dis Ther 2016; 4: 264.

16. Retnaningsih DAS. Voluntary Counseling and Testing untuk Orang Berisiko HIV/AIDS [Voluntary Counseling and Testing for People at Risk of HIV/AIDS]. J Dakwah dan Komun Al-Balagh IAIN Surakarta 2016; 1: 115-128.

17. Wulandari SI, Kusyogo C, Syamsulhuda BM. Faktor-Faktor Yang Berhubungan Dengan Perilaku Wanita Pekerja Seks (PSP) Untuk Melakukan VCT Di Lokalisasi Tegal Panas Kabupaten Semarang [Factors Associated with Female Sex Worker Behaviour to access VCT in Tegal Panas Localisation in Semarang]. J Kesehat Masy 2015; 3: 669-678.

18. Tokar A, Broerse JEW, Blanchard J, Roura M. HIV testing and counseling among female sex workers: a systematic literature review. AIDS Behav 2018; 22: 2435-2457.

19. Putra IGNE, Phuengsamran D, Jampaklay A, Thammawijaya P, Januraga PP. Psychological factors associated with protected sex among indirect female sex workers in Denpasar, Bali, Indonesia. AIDS Care 2020; 32: 749-757.

20. Januraga PP, Mooney-Somers J, Gesesew HA, Ward PR. The logic of condom use in female sex workers in Bali, Indonesia. Int J Environ Res Public Health 2020; 17: 1627.

21. Indonesian Institute of Sciences. Buku Saku Klirens Etik Penelitian [Research Ethics Pocket Book]. Jakarta: LIPI; 2016.

22. Ma PHX, Chan ZCY, Yuen A. The socio-ecological model approach to understanding barriers and facilitators to the accessing of health services by sex workers : a systematic review. AIDS Behav 2017; 21: 2412-2438.

23. King EJ, Maman S, Bowling JM, Moracco KE, Dudina V. The influence of stigma and discrimination on female sex workers' ac- cess to HIV services in St. Petersburg, Russia. AIDS Behav 2013; 17: 2597-2603.

24. Januraga PP, Reekie J, Mulyani T, et al. The cascade of HIV care among key populations in Indonesia: a prospective cohort study. Lancet HIV [Internet]. 2018; 5: e560-568. Available from: https:// linkinghub.elsevier.com/retrieve/pii/S2352301818301486.

25. Xu J, Brown K, Ding G, et al. Factors associated with HIV testing history and HIV-test result follow-up among female sex workers in two cities in Yunnan, China. Sex Transm Dis 2011; 38: 89-95.

26. Khumalo-Sakutukwa G, Morin SF, Fritz K, et al. Project accept (HPTN 043): A community-based intervention to reduce HIV incidence in populations at risk for HIV in Sub-Saharan Africa and Thailand. J Acquir Immune Defic Syndr 2009; 49: 422-431.

27. Widianto SG. Faktor-faktor yang Berhubungan dengan Praktik Wanita Pekerja Seks (PSP) dalam VCT Ulang di Lokalisasi Sunan Kuning Kota Semarang [Factors Associated with VCT retaking of Female Sex Workers in Sunan Kuning Localisation in Semarang City]. J Promosi Kesehat Indones 2009; 4: 25-35.

28. Bates J, Berg R. Sex workers as safe sex advocates: sex workers protect both themselves and the wider community from HIV. AIDS Educ Prev 2014; 26: 191-201.

29. Lundgren J, Phillips A. Comment prevention of HIV transmission by antiretroviral therapy. Lancet HIV 2017; 3018: 9-10.

30. Chanda MM, Ortblad KF, Mwale M, et al. HIV self-testing among female sex workers in Zambia: a cluster randomized controlled trial. PLoS Med 2017; 14: e1002442. 